\title{
The effect of oestrogen and dietary phyto-oestrogens on transepithelial calcium transport in human intestinal-like Caco-2 cells
}

\author{
Alice A. Cotter ${ }^{1}$, Christopher Jewell ${ }^{1}$ and Kevin D. Cashman ${ }^{1,2} *$ \\ ${ }^{1}$ Department of Food and Nutritional Sciences and \\ ${ }^{2}$ Department of Medicine, University College, Cork, Ireland
}

(Received 28 January 2002 - Revised 16 December 2002 - Accepted 16 January 2003)

\begin{abstract}
Recently, dietary phyto-oestrogens (PO) have been suggested as possible alternatives to oestrogen therapy (hormone replacement therapy) as a means of preventing bone loss associated with ovarian hormone deficiency. While PO, which exhibit oestrogen-like activity, act directly on bone cells, their protective effect on bone may be partly due to their ability to enhance $\mathrm{Ca}$ absorption. Therefore, the aim of the present study was to investigate the effect of $17 \beta$-oestradiol and two commonly consumed soyabean PO (genistein and daidzein) on Ca absorption in the human Caco-2 intestinal-like cell model. Caco-2 cells were seeded onto permeable filter supports and allowed to differentiate into monolayers. On day 21, the Caco-2 monolayers ( $n$ 8-18 per treatment), grown in oestrogen-replete or -deplete media, were then exposed to $10 \mathrm{nM}-17 \beta$-oestradiol, $1 \mathrm{nM}-1,25$-dihydroxycholecalciferol, or $50 \mu \mathrm{M}$-genistein or -daidzein for $24 \mathrm{~h}$. After exposure, transepithelial and transcellular transport of ${ }^{45} \mathrm{Ca}$ and fluorescein transport (a marker of paracellular diffusion) were measured. As expected, 1,25-dihydroxycholecalciferol stimulated $\mathrm{Ca}$ absorption in Caco-2 cells, by up-regulating transcellular transport, whereas $17 \beta$-oestradiol had no effect on Ca absorption. Unexpectedly, both PO decreased $\mathrm{Ca}$ absorption (by about $17-19 \%$ compared with control, $P<0.05$ ), by reducing transcellular $\mathrm{Ca}$ transport in Caco-2 cells grown in oestrogen-replete media. This inhibitory effect disappeared when monolayers were grown in oestrogen-deplete media. In conclusion, PO at high luminal concentrations either had no effect or reduced $\mathrm{Ca}$ absorption in Caco-2 cells, dependent on oestrogen status. The effect of lower concentrations of these compounds needs to be investigated.
\end{abstract}

Oestrogen: Phyto-oestrogens: Calcium absorption: Caco-2 cells

Oestrogen deficiency is a major contributory factor to the development of osteoporosis in women. In postmenopausal women it is associated with increased bone turnover and acceleration of bone loss, leading to increased susceptibility to bone fractures (Riggs \& Melton, 1986; Nguyen et al. 1995). Oestrogen therapy (or hormone replacement therapy) remains the mainstay for prevention of bone loss in postmenopausal women (Gallagher, 2001). Decreased $\mathrm{Ca}$ absorption due to ovarian hormone deficiency is also corrected by hormone replacement therapy (Heaney et al. 1978; Gallagher et al. 1980; for review, see Gallagher, 1990). However, fewer than one in four postmenopausal women decide to use hormone replacement therapy, and within 6 months, $>60 \%$ of them withdraw due to concerns over an increased risk of malignancy and other side effects (Taylor, 1997).

Recently, attention has been focused on the so-called dietary phyto-oestrogens (PO) as possible alternatives, or at least adjuncts, to hormone replacement therapy. The PO are non-steroidal compounds naturally occurring in foods of plant origin (especially soyabean-based foods), and they are able to compete with the principle oestrogens of most mammals (17 $\beta$-oestradiol and oestrone) for binding oestrogen receptors (OR; Cassidy, 1996). Several studies have shown that when ovariectomized rats were treated with either soyabean with its naturally-occurring isoflavones, a genistein-rich soyabean isoflavone preparation or purified genistein or diadzein, they retained

\footnotetext{
Abbreviations: FBS, fetal bovine serum; LDH, lactate dehydrogenase; MTT, 3-(4,5-dimethylthiozol-2-yl)-2,5-diphenyltetrazolium bromide; Neutral Red, 3-amino-7-dimethylamino-2-methylphenazine hydrochloride; OR, oestrogen receptor; PO, phyto-oestrogen; TEER, transepithelial electrical resistance; $1,25(\mathrm{OH})_{2} \mathrm{D}_{3}, 1,25$-dihydroxycholecalciferol.

* Corresponding author: Professor Kevin D. Cashman, fax +353 21 4270244, email k.cashman@ucc.ie
} 
significantly more bone mass than untreated, control animals (Blair et al. 1996; Arjmandi et al. 1996, 1998a,b; Picherit et al. 2000, 2001). To date, a limited number of relatively short-term (3-6 months) clinical studies with small subject numbers (n 37-69) have examined the effect of soyabean protein or soyabean protein isolate with normal or reduced isoflavone levels on bone mineral density and/or bone mineral content (Dalais et al. 1998; Potter et al. 1998; Alekel et al. 2000; Hsu et al. 2001) and these have produced inconclusive results (for reviews, see Arjmandi, 2001; Arjmandi \& Smith, 2002). Interestingly, Morabito et al. (2002) recently reported that in a randomized double-blind placebo controlled study, genistein treatment $(56 \mathrm{mg} / \mathrm{d})$ for 12 months was as effective as hormone replacement therapy in preventing bone loss in early postmenopausal women.

While PO act directly on bone cells (Gao \& Yamaguchi, 2000; Yamaguchi \& Sugimoto, 2000), it is also conceivable that their protective effect on bone may be partly due to their ability to enhance $\mathrm{Ca}$ absorption. Some of the PO compounds structurally resemble oestrogen (Anderson et al. 1999), and thus, similarly to oestrogen (Heaney et al. 1978; Gallagher et al. 1980; for review, see Gallagher, 1990) may have the ability to enhance intestinal $\mathrm{Ca}$ absorption. In support of this contention, Omi et al. (1994) reported that intestinal Ca absorption was significantly $(P<0.05)$ greater in ovariectomized rats given soyabean milk-containing diets (rich in phyto-oestrogenic compounds such as genistein and daidzein) than in rats given a control diet (containing no soyabean milk) for $28 \mathrm{~d}$. The authors suggest that it is possible that the enhancement in intestinal $\mathrm{Ca}$ absorption was the mechanism by which bone mineral density and mechanical strength of bone was significantly increased $(P<0.05)$ in the rats fed the soyabean milk-containing diet relative to control animals. In addition, Arjmandi et al. (2002) recently reported that the rate of in vitro $\mathrm{Ca}$ transport by intestinal cells of ovariectomized rats fed soyabean protein with normal isoflavone content was significantly $(P<0.05)$ greater than that from ovarectomized control animals. The effect, however, of isolated phyto-oestrogenic compounds, such as genistein and daidzein, on $\mathrm{Ca}$ absorption in rats has not been reported. Ipriflavone, a synthetic PO that has a bone-sparing effect in rats (Arjmandi et al. 2000) and human subjects (Agnusdei et al. 1997; Gennari et al. 1998; Ohta et al. 1999), has also been shown to enhance in vitro $\mathrm{Ca}$ uptake by rat duodenal cells (Arjmandi et al. 2000).

Whether PO mediate a reduction in bone loss via a direct positive effect on bone metabolism, or because of a positive effect on $\mathrm{Ca}$ absorption, is not known. Therefore, the aim of the present study was to investigate the effect of $17 \beta$-oestradiol, two commonly consumed soyabean PO (genistein and daidzein) and the parent compounds of the latter (genistin and daidzin, which do not have oestrogenic activity (Miksicek, 1995)), on Ca absorption in human Caco-2 intestinal-like cells.

Caco- 2 cells have been suggested to be a suitable model for predicting $\mathrm{Ca}$ absorption in human subjects (Giuliano \& Wood, 1991; Fleet \& Wood, 1999). In culture, Caco-2 cells spontaneously differentiate and form a polarized epithelial monolayer with tight junctions and express a differentiated cell phenotype consistent with absorptive small intestinelike enterocytes (Pinto et al. 1983; Yee, 1997). In particular, these cells have a functional vitamin D receptor (Giuliano et al. 1991) and have Ca transport kinetics that suggest the presence of both a saturable and non-saturable $\mathrm{Ca}$ transport pathway, similar to that which has been observed in the intestine of human subjects and animals (Fleet \& Wood, 1999). 1,25-Dihydroxycholecalciferol $\left(1,25(\mathrm{OH})_{2} \mathrm{D}_{3}\right)$ treatment induces the saturable, but not diffusional, component of $\mathrm{Ca}$ transport (Giuliano \& Wood, 1991) and induces accumulation of calbindin $D_{9 K}$ and 24-hydroxylase mRNA in these cells (Fleet \& Wood, 1994; Fleet et al. 1996). In addition, the Caco-2 cells possess an OR (Campbell-Thompson et al. 2001). Therefore, this relatively simple in vitro method appears to be a good model for predicting $\mathrm{Ca}$ bioavailability in human subjects.

\section{Materials and methods}

Materials

Tissue culture materials, including Dulbecco's modified Eagle's medium with L-glutamine and sodium bicarbonate, fetal bovine serum (FBS), minimum essential medium, nonessential amino acids and PBS were purchased from SigmaAldrich Ireland Ltd, Dublin, Ireland. ${ }^{45} \mathrm{Ca}$ (as ${ }^{45} \mathrm{Ca}$ in an aqueous solution of $\mathrm{CaCl}_{2}$, with a specific activity of $1.85 \mathrm{MBq} / \mathrm{mg} \mathrm{Ca}$ ) was purchased from Nensure ${ }^{\mathrm{TM}}$, Boston, MA, USA. Fluorescein sodium salt, 3-(4,5-dimethylthiozol-2-yl)-2,5-diphenyltetrazolium bromide (MTT), 3-amino- 7-dimethylamino-2-methylphenazine hydrochloride (Neutral Red), $17 \beta$-oestradiol, $1,25(\mathrm{OH})_{2} \mathrm{D}_{3}$, genistein, daidzein, genistin and daidzin were purchased from SigmaAldrich Ireland Ltd.

\section{Conditions of cell culture}

The human colon adenocarcinoma cell line, Caco-2, was purchased from the European Collection of Animal Cell Cultures (Salisbury, Wilts., UK). Cells were routinely grown in $75 \mathrm{~cm}^{2}$ plastic culture flasks (Costar, Cambridge, MA, USA) in Dulbecco's modified Eagle's medium supplemented with non-essential amino acids $(10 \mathrm{ml} / \mathrm{l})$ and FBS $(100 \mathrm{ml} / \mathrm{l})$. Caco-2 cells were maintained at $37^{\circ} \mathrm{C}$ in $\mathrm{CO}_{2}-$ air $(5: 95, \mathrm{v} / \mathrm{v})$. Cells were seeded at $3 \times 10^{4}$ / $\mathrm{cm}^{2}$ and passaged when reaching $90 \%$ confluency. Cells used in transepithelial $\mathrm{Ca}$ transport experiments were seeded at a density of $3 \times 10^{4} / \mathrm{cm}^{2}$ onto permeable Transwell $^{\circledR}$ filter inserts $(24 \mathrm{~mm}$ diameter, $0.4 \mu \mathrm{m}$ pore size; Costar). Cell culture media (with FBS and containing Phenol Red) was changed on alternate days for $21 \mathrm{~d}$. In one series of experiments, cell culture media (with FBS and containing Phenol Red) was changed on alternate days for $18 \mathrm{~d}$ after which cell culture media (without FBS and Phenol Red-free) was used for the last $3 \mathrm{~d}$ before the $\mathrm{Ca}$ transport study. These conditions created a low-oestrogen status for the Caco-2 cells immediately preceding their exposure to treatments. For mRNA studies, cells $\left(3 \times 10^{4} / \mathrm{cm}^{2}\right)$ were seeded into six-well culture plates 
(35 mm diameter; Costar). For viability studies, cells $\left(3 \times 10^{4} / \mathrm{cm}^{2}\right)$ were seeded into six-well and forty-eightwell culture plates (Costar).

\section{Cell viability and cytotoxicity assays}

The effect of $17 \beta$-oestradiol, $1,25(\mathrm{OH})_{2} \mathrm{D}_{3}$, genistein, genistin, daidzein and daidzin on Caco- 2 cell viability was investigated using the MTT (Mossman, 1983; Edmonson et al. 1988) and Neutral Red (Hunt et al. 1987) cell viability assays in forty-eight-well culture plates (Costar). Briefly, cells were seeded into forty-eight-well plates at $3 \times 10^{4} / \mathrm{cm}^{2}$ and allowed to grow for $21 \mathrm{~d}$. Cells were then treated for $24 \mathrm{~h}$ with test compounds. Stock solutions of all test compounds were prepared in dimethyl sulfoxide, except for $1,25(\mathrm{OH})_{2} \mathrm{D}_{3}$, which was prepared in absolute ethanol. Test compounds were diluted in tissue culture medium with a final concentration of the carrier solvent not exceeding $2 \mathrm{ml} / 1$. For the MTT assay, following the $24 \mathrm{~h}$ exposure to the test compounds, $100 \mu$ l stock solution of MTT (3 mg/ml PBS, pH 7.4) was added to each well and the culture plate was incubated for a further $3 \mathrm{~h}$ at $37^{\circ} \mathrm{C}$. The medium was then removed and the forty-eight-well culture plate was frozen at $-20^{\circ} \mathrm{C}$ overnight. After thawing, isopropanol $(1 \mathrm{ml})$ was added to each well to solubilize the formazan dye. The absorbance was read at $570 \mathrm{~nm}$ on a plate reader. Results were expressed as a percentage of control representing the surviving fraction relative to control samples. A value $<85 \%$ of the control value was taken as a benchmark for toxicity. For the Neutral Red assay, following the $24 \mathrm{~h}$ exposure to the test compounds, $1 \mathrm{ml}$ media containing Neutral Red (50 mg Neutral Red (dissolved in $500 \mu$ l dimethyl sulfoxide)/l media) was added to each well and the forty-eight-well culture plate was incubated for a further $3 \mathrm{~h}$ at $37^{\circ} \mathrm{C}$. The medium was then removed and $\mathrm{PBS}$ added to each well. Following the removal of PBS, glacial acetic acid $(10 \mathrm{~g} / \mathrm{l}$ ethanol $(500 \mathrm{ml} / \mathrm{l})$ was added to solubilize the dye. The absorbance was read at $570 \mathrm{~nm}$ on a plate reader. Results were expressed as a percentage of the control value representing the surviving fraction relative to control samples. A value $<85 \%$ of the control value was taken as a benchmark for toxicity.

Lactate dehydrogenase (LDH) release from cells into the surrounding medium was determined as an index of cytotoxicity (Vassault, 1983). Cells were seeded into six-well plates at $3 \times 10^{4} / \mathrm{cm}^{2}$ and grown for $21 \mathrm{~d}$. Cells were exposed to the test compounds for $24 \mathrm{~h}$ as described for the MTT and Neutral Red assays. A portion $(40 \mu l)$ of medium was taken from each well for LDH analysis and placed in a forty-eight-well plate. The remaining medium was then removed from the cells and the cells washed with PBS. The cells were then scraped and suspended in a solution of Triton X-100 ( $10 \mathrm{ml} / 1$ distilled water). The suspended cells were placed in Eppendorf tubes and sonicated on ice for $10 \mathrm{~s}$. Samples were left on ice for $30 \mathrm{~min}$ and then centrifuged for $10 \mathrm{~min}$ at $1500 \mathrm{~g}$. LDH analysis was carried out using a commercially available colorimetric kit assay (product no. DK1340-K; SigmaAldrich Ireland Ltd). The decrease in rate of absorbance (measured at $340 \mathrm{~nm}$ ) for each sample was determined (due to formation of NAD, as $\mathrm{LDH}$ reduces pyruvate to lactate). $\mathrm{LDH}$ release into the medium was expressed as a percentage of total LDH released from cells treated with Triton X-100.

\section{7 $\beta$-Oestradiol stimulation of Caco-2 cell growth}

The responsiveness of Caco- 2 cells to $17 \beta$-oestradiolstimulated cell growth was assessed by the method of Di Domenico et al. (1996). In brief, Caco-2 cells were seeded at $3 \times 10^{4} / \mathrm{cm}^{2}$ in $25 \mathrm{~cm}^{2}$ plastic culture flasks (Costar) in Dulbecco's modified Eagle's medium, supplemented with non-essential amino acids $(10 \mathrm{ml} / \mathrm{l})$ and charcoal stripped heat-inactivated FBS $(50 \mathrm{ml} / \mathrm{l})$. Following $24 \mathrm{~h}$ adherence to the flask, media was removed and cells were fed media without $17 \beta$-oestradiol (control) or media containing $17 \beta$-oestradiol $(10 \mathrm{nM})$ with or without $1 \mu \mathrm{M}$ 4-hydroxytamoxifen (Sigma-Aldrich Ireland Ltd). In order to achieve maximum effect, $1 \mu \mathrm{M}$-4-hydroxytamoxifen was added $1 \mathrm{~h}$ prior to addition of $17 \beta$-oestradiol. Media were replaced every second day for $6 \mathrm{~d}$. On days 2, 3, 5 and 6 cells were passaged using Phenol Red-free trypsin-EDTA and cells counted in a haemocytometer in quadruplicate. Each experiment was carried out in triplicate.

\section{Transepithelial electrical resistance}

For all transport experiments, the transepithelial electrical resistance (TEER) was checked prior to the experiment by a Millicell ${ }^{\circledR}$ ERS meter (Millipore Corp., Bedford, MA, USA) connected to a pair of thin side-by-side electrodes. TEER readings were taken at $37^{\circ} \mathrm{C}$. A TEER value $\geq 400 \Omega \cdot \mathrm{cm}^{2}$ was used as an indicator that the epithelial layer was intact and ready to use for $\mathrm{Ca}$ transport studies.

\section{Cell treatments}

For Ca transport experiments, cells grown in the Transwell ${ }^{\circledR}$ inserts (Costar) were treated with vehicle only (for control), $1 \mathrm{nM}-1,25(\mathrm{OH})_{2} \mathrm{D}_{3}$ (positive control), $10 \mathrm{nM}$ $17 \beta$-oestradiol or $50 \mu \mathrm{M}$-genistein, -genistin, -daidzein or -daidzin for $24 \mathrm{~h}$. All compounds were added to complete culture medium prior to their addition to the cells. The vehicle never exceeded $2 \mathrm{ml} / \mathrm{l}$. TEER measurements were taken immediately prior to treatment with test compounds and $24 \mathrm{~h}$ after treatment.

\section{Transepithelial calcium transport studies}

The method used for determining $\mathrm{Ca}$ transport across the Caco-2 membrane in the present study is a modification of the methods of Giuliano \& Wood (1991) and Fleet \& Wood (1994). Transepithelial transport of Ca was studied with Caco- 2 cells grown on permeable membrane supports for $21 \mathrm{~d}$, by which time the cells are fully differentiated. On the day of an experiment, after cells were treated for $24 \mathrm{~h}$ with the test compounds, the medium was removed and the inserts rinsed with buffer. The buffer was prepared fresh before use and consisted of $140 \mathrm{mM}-\mathrm{NaCl}, 5.8 \mathrm{mM}-$ $\mathrm{KCl}, 1.2 \mathrm{~mm}-\mathrm{CaCl}_{2}, 0.8 \mathrm{~mm}-\mathrm{MgSO}_{4}, 0.44 \mathrm{~mm}-\mathrm{KH}_{2} \mathrm{PO}_{4}$, 
0.34 mM-Na ${ }_{2} \mathrm{HPO}_{4}, 4 \mathrm{~mm}$-glutamine, $25 \mathrm{~mm}$-glucose and 20 mM-4-(2-hydroxy-ethyl)-1-piperazine-ethanesulfonic acid, $\mathrm{pH} 7.4$. After rinsing, $2.6 \mathrm{ml}$ buffer was added to the lower chamber of the Transwell ${ }^{\circledR}$ inserts (Costar). At time $0,1.5 \mathrm{ml}$ transport buffer was added to the upper chamber of the Transwell ${ }^{\circledR}$ inserts. This consisted of the same buffer as the lower chamber except it also contained ${ }^{45} \mathrm{Ca}$ (with an activity of $148 \mathrm{kBq} / \mathrm{ml}$ ) and $5.3 \mathrm{~mm}$-fluorescein (as the sodium salt). Fluorescein was included in the transport buffer as a means of measuring paracellular (diffusional) transport across the Caco-2 monolayer (Lindmark et al. 1998). Following the addition of the transport buffer to the Transwell ${ }^{\circledR}$ inserts (Costar) the plates were covered and incubated at $37^{\circ} \mathrm{C}$ in a shaking water-bath (set to forty-eight oscillations per min) for $60 \mathrm{~min}$. At 30 and $60 \mathrm{~min}$ after addition of ${ }^{45} \mathrm{Ca}$-labelled transport buffer, duplicate portions $(10 \mu \mathrm{l})$ of the buffer from the lower chamber (basolateral buffer) were taken from each well and placed in wells of a blackened ninety-six-well plate (Costar). When samples had been taken at both time points, $200 \mu 150 \mathrm{mM}$ - $n$-ethylmorpholine buffer ( $\mathrm{pH} 8 \cdot 0)$ was added to each of the ninety-six wells and fluorescence (excitation $485 \mathrm{~nm}$, emission $535 \mathrm{~nm}$ ) was measured in a Spectraflur+ Tecan fluorescence plate reader (Hombrechtikon, Switzerland). In addition, at the same time points duplicate portions $(50 \mu 1)$ of the basolateral buffer were taken for determination of ${ }^{45} \mathrm{Ca}$ content. Samples of the basolateral buffer were placed in scintillation vials and $5 \mathrm{ml}$ liquid scintillation cocktail (biodegradable counting scintillant; Amersham International Plc., Amersham, Bucks., UK) was added to each vial. Counts were measured on a Beckman LS 6500 multipurpose liquid scintillation counter (Beckman Instruments Inc., Fullerton, CA, USA). An equal volume of fresh basolateral buffer was added back to the lower chamber following each sampling point. The concentration of fluorescein appearing in the lower buffer after 60 min was determined using a standard curve of fluorescein and this value was expressed as a percentage of the total fluorescein added to the upper chamber of the Transwell ${ }^{\circledR}$ inserts (Costar). This represented the paracellular route of $\mathrm{Ca}$ transport. The amount of ${ }^{45} \mathrm{Ca}$ appearing in the basolateral buffer was expressed as a percentage of the total ${ }^{45} \mathrm{Ca}$ applied to the upper chamber. This represented total transepithelial ${ }^{45} \mathrm{Ca}$ transport (i.e. by both the paracellular and transcellular transport routes) and was expressed both as $\% / \mathrm{h}$ and nmol transported/min per well during the $30-60 \mathrm{~min}$ time interval. By subtracting the percentage of fluorescein transport per $\mathrm{h}$ from the total ${ }^{45} \mathrm{Ca}$ transport $(\% / \mathrm{h})$, the amount of ${ }^{45} \mathrm{Ca}$ crossing the Caco- 2 cell monolayer by the transcellular (active) route was calculated and expressed as nmol/ well per min. In all studies, at least three wells were examined per treatment. Experiments were repeated three times.

\section{Reverse transcription-polymerase chain reaction analysis for mRNA levels}

After experimental treatments, cells (grown in FBS-Phenol Red-containing media) were harvested and RNA was isolated and analysed for calbindin $\mathrm{D}_{9 \mathrm{~K}}$ and glyceraldehyde-3-phosphate dehydrogenase. RNA was also isolated from post-confluent, fully differentiated Caco-2 cells (grown in FBS-Phenol Red-containing media) and analysed for $\mathrm{OR} \alpha$ and $-\beta$. mRNA levels were determined by reverse transcription-polymerase chain reaction analysis (Wood et al. 2001). The glyceraldehyde-3-phosphate dehydrogenase mRNA level was used as a constitutively expressed control gene. Primer sets for glyceraldehyde-3phosphate dehydrogenase, calbindin $D_{9 K}, O R \alpha$ and $-\beta$ were derived from previously published sequences (Fleet \& Wood, 1994; Arai et al. 2000; Wood et al. 2001). To minimize the potential for variability in the reverse transcriptase reaction, cDNA was prepared from total cellular RNA for all samples at the same time, using the same reagents. Polymerase chain reaction products were subjected to electrophoresis (agarose (2\%) gel). Relative amounts of amplified polymerase chain reaction product from each experimental condition were visualized under u.v. light and digitized with the Kodak Digital Science DC 120 Zoom Digital Camera and Electrophoresis Documentation System (Eastman Kodak Company, Rochester, NY, USA). Relative amounts of the product were estimated by digital densitometry using Kodak Digital Science Analysis System 120 quantification software (Eastman Kodak Company, Scientific Imaging Systems, Rochester, $\mathrm{NY}$, USA). Calbindin $\mathrm{D}_{9 \mathrm{~K}}$ expression was normalized relative to the expression of glyceraldehyde-3-phosphate dehydrogenase mRNA.

\section{Statistical methods}

Data for all variables (except the \% LDH release data) were normally distributed and allowed for parametric tests of significance. The \% $\mathrm{LDH}$ release data was cos transformed prior to statistical analysis, to achieve a near-normal distribution. Results are presented as mean values with their standard errors. Treatment effects were compared by one-way ANOVA, with variation attributed to concentration of treatment compound (cell viability and cytotoxicity data) or type of treatment compound (cell growth data and $\mathrm{Ca}$ transport data) (Snedecor \& Cochran, 1967). To follow up the ANOVA, all pairs of mean values were compared by the method of least significant difference (Snedecor \& Cochran, 1967).

\section{Results}

Treatment with $50 \mu \mathrm{M}$-genistein, -genistin, -daidzein, or -daidzin for $24 \mathrm{~h}$ had no cytotoxic effects in Caco- 2 cells, relative to controls, as assessed by the LDH release assay (Fig. 1). There was no effect of incremental concentrations $(0-50 \mu \mathrm{M})$ of genistein, genistin, daidzein and daidzin on Caco- 2 cell survival and viability after $24 \mathrm{~h}$ of exposure as determined using the MTT assay, which is based on mitochondrial dehydrogenase activity, and the Neutral Red assay, which is based on cellular uptake of the dye (results not shown). In addition, exposure of Caco- 2 cells to $1,25(\mathrm{OH})_{2} \mathrm{D}_{3}$ (positive control for the $\mathrm{Ca}$ transport experiments) and $17 \beta$-oestradiol (in the range of $10^{-10}-10^{-6} \mathrm{M}$ for both compounds) for $24 \mathrm{~h}$ had no effect on cell viability, using the MTT and Neutral Red assays, or on cell cytotoxicity (at a concentration of $1 \mathrm{nM}$ 


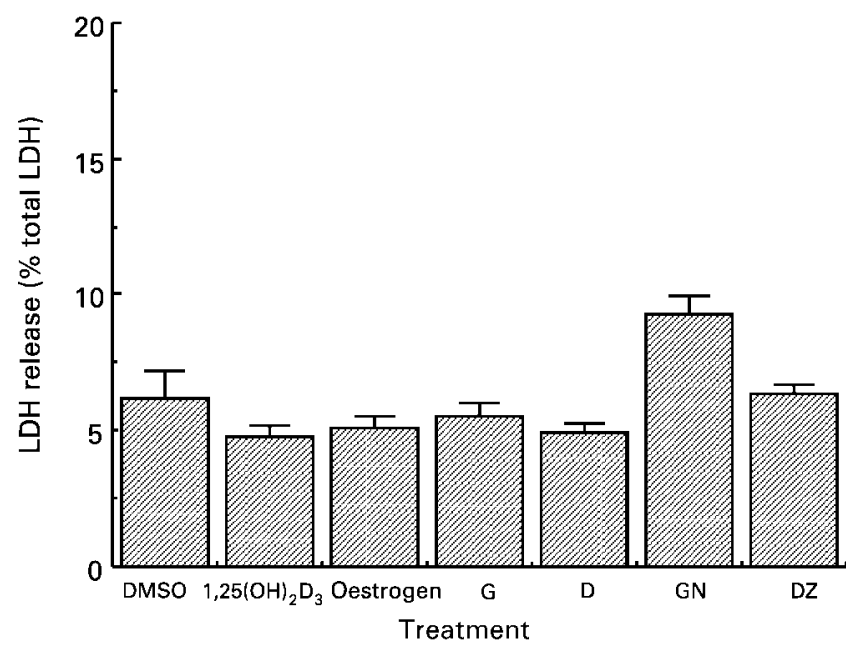

Fig. 1. Effect of treatment for $24 \mathrm{~h}$ on the percentage of lactate dehydrogenase (LDH) release from Caco-2 cells. LDH activity in the medium was measured and expressed as a percentage of total LDH released from Caco-2 cells treated with Triton X-100 (for further details, see p. 756). Treatments were: dimethyl sulfoxide (DMSO, control); $1 \mathrm{nM}-1,25$-dihydroxycholecalciferol $\left(1,25\left(\mathrm{OH}_{2}\right) \mathrm{D}_{3}\right)$; $10 \mathrm{~nm}$-17ß-oestradiol (oestrogen); $50 \mu \mathrm{M}$-genistein (G); $50 \mu \mathrm{M}$-daidzein (D); $50 \mu \mathrm{M}$-genistin (GN); $50 \mu \mathrm{M}$-daidzin (DN). Values are means with their standard errors shown by vertical bars for at least three independent experiments. Data were not normally distributed and thus were transformed (cos) before statistical analysis. The effect of treatment on \% LDH release was analysed using one-way ANOVA of the (cos) transformed data. No significant $(P>0.05)$ concentration effects were found.

for $1,25(\mathrm{OH})_{2} \mathrm{D}_{3}$ and $10 \mathrm{nM}$ for $17 \beta$-oestradiol), using the LDH release assay (results not shown).

The post-confluent, fully differentiated Caco- 2 cells used in the present study (grown in FBS-Phenol Red-containing media) expressed mRNA for OR $\beta$ but not $-\alpha$ (Fig. 2). cDNA from MCF-7 (breast cancer) and OVCAR-1 (ovarian cancer) cells in culture were used as positive controls for mRNA for $\mathrm{OR} \alpha$ and $-\beta$ respectively.

Addition of $10 \mathrm{nM}-17 \beta$-oestradiol to the Phenol Red-free medium containing charcoal-stripped, heat-inactivated FBS

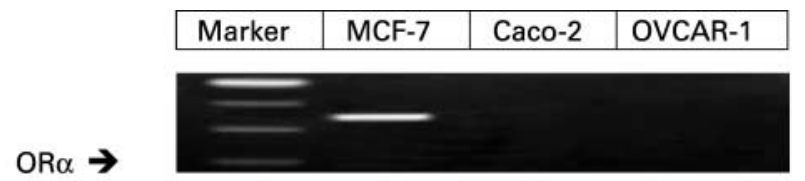

OR $\beta \rightarrow$

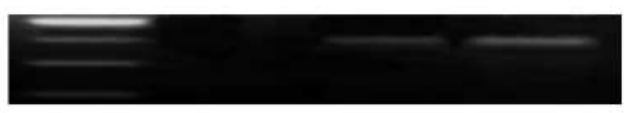

\section{GAPDH $\rightarrow$}

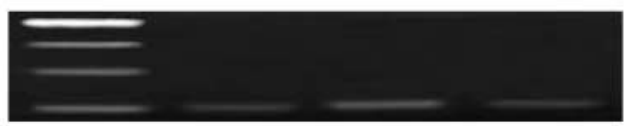

Fig. 2. Expression of oestrogen receptor (OR) $\beta$ but not $\mathrm{OR} \alpha$ in Caco-2 cells. Reverse transcriptase-polymerase chain reaction for $\mathrm{OR} \alpha$ or $-\beta$ and glyceraldehyde-3-phosphate dehydrogenase (GAPDH) were performed simultaneously on mRNA from MCF-7 (breast) cells or from OVCAR-1 (ovarian) cells (positive controls for $\mathrm{OR} \alpha$ and $-\beta$ respectively) and on mRNA from Caco- 2 cells. Marker, 500 (double band), 400, 300 and $200 \mathrm{bp}$. For details of procedures, see p. 756. Representative ethidium bromide staining of $\mathrm{OR} \alpha$ (345 bp), OR $\beta$ (393 bp) and GAPDH (200 bp) transcripts. induced a significant $(P<0 \cdot 001)$ increase in Caco-2 cell number (Fig. 3). Inclusion of $1 \mu \mathrm{M}$-4-hydroxytamoxifen, a partial oestrogen agonist, prevented the $17 \beta$-oestradiolinduced proliferative effect (Fig. 3).

Treatment of fully differentiated Caco- 2 cell monolayers (grown in media containing FBS and Phenol Red) with 1 $\mathrm{nM}-1,25(\mathrm{OH})_{2} \mathrm{D}_{3}, 10 \mathrm{nM}-17 \beta$-oestradiol, or $50 \mu \mathrm{M}$-genistein, -genistin, -daidzein or -daidzin for $24 \mathrm{~h}$ had no effect on TEER in the present study (Tables 1 and 2).

Treatment of Caco-2 cell monolayers (grown in media containing FBS and Phenol Red) with $1 \mathrm{nM}-1,25(\mathrm{OH})_{2} \mathrm{D}_{3}$ for $24 \mathrm{~h}$ significantly $(P<0.05)$ increased the total transepithelial $\mathrm{Ca}$ transport compared with control values (Tables 1 and 2). Furthermore, while paracellular Ca transport (as indicated by fluorescein transport) was unaffected, transcellular $\mathrm{Ca}$ transport was significantly increased $(P<0.05)$ by the $1,25(\mathrm{OH})_{2} \mathrm{D}_{3}$ treatment (Tables 1 and 2$)$.

Treatment of Caco-2 cell monolayers (grown in media containing FBS and Phenol Red) with $10 \mathrm{nM}-17 \beta$-oestradiol for $24 \mathrm{~h}$ had no effect on total transepithelial, paracellular or transcellular Ca transport (Table 1). Unexpectedly, treatment of Caco- 2 cell monolayers (grown in media containing FBS and Phenol Red) with $50 \mu \mathrm{M}$-genistein or -daidzein for $24 \mathrm{~h}$ significantly $(P<0.05)$ decreased total transepithelial $\mathrm{Ca}$ transport, by about 19 and about $17 \%$ respectively compared with control values (Table 1). Furthermore, while paracellular transport was unaffected, transcellular $\mathrm{Ca}$ transport was significantly $(P<0.05)$ decreased by treatment with both PO (Table 1).

Treatment of Caco-2 cell monolayers (grown in media containing FBS and Phenol Red) with $50 \mu \mathrm{M}$-genistin or -daidzin (the parental compounds for genistein and daidzein respectively) for $24 \mathrm{~h}$ had no effect on total transepithelial, paracellular or transcellular $\mathrm{Ca}$ transport (Table 2).

Total transepithelial, paracellular and transcellular $\mathrm{Ca}$ transport were unaffected in Caco- 2 cell monolayers in

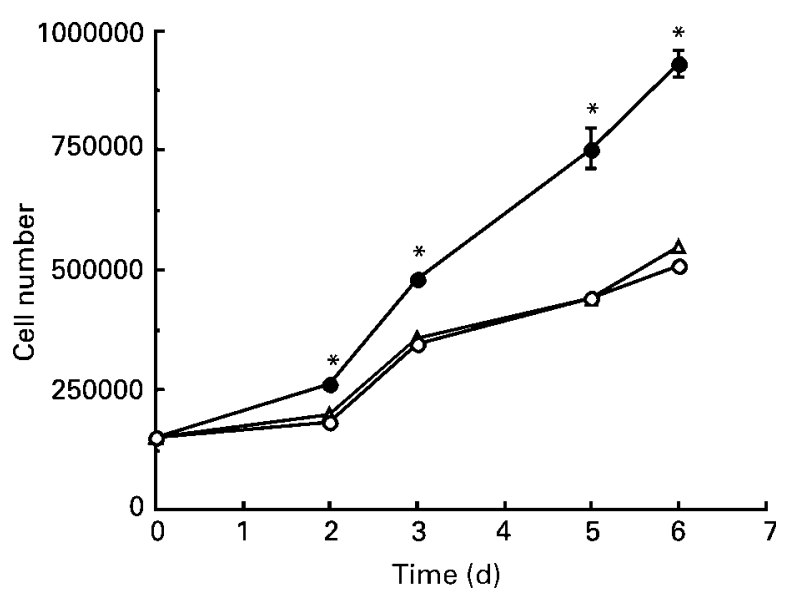

Fig. 3. Effect of $17 \beta$-oestradiol and partial oestrogen agonist (hydroxytamoxifen) on Caco-2 cell growth. Cells were grown in the absence $(O)$ (control) and in the presence of either $10 \mathrm{~nm}-17 \beta$ oestradiol (0) or $10 \mathrm{~nm}-17 \beta$-oestradiol and $1 \mu \mathrm{M}$-hydroxytamoxifen $(\Delta)$. For details of procedures, see p. 756 . Values are means with their standard errors shown by vertical bars for the cell number of each well averaged from three different experiments. Means values were significantly different from those of the controls: ${ }^{\star} P<0.05$ 
Table 1. Effect of $17 \beta$-oestradiol, genistein, diadzein and 1,25 -dihydroxycholecalciferol $\left(1,25(\mathrm{OH})_{2} \mathrm{D}_{3}\right)$ on calcium transport in Caco-2 cell monolayers cultured in oestrogen-replete media*

(Mean values with their standard errors)

\begin{tabular}{|c|c|c|c|c|c|c|c|c|c|c|c|}
\hline \multirow[b]{4}{*}{ Treatment $†$} & \multirow[b]{4}{*}{$n$} & \multicolumn{8}{|c|}{ Calcium transport } & & \\
\hline & & \multicolumn{4}{|c|}{ Total transepithelial } & \multirow{2}{*}{\multicolumn{2}{|c|}{$\begin{array}{l}\text { Transcellular } \\
\text { (nmol/well per } \\
\text { min) } \ddagger\end{array}$}} & \multirow{2}{*}{\multicolumn{2}{|c|}{$\begin{array}{l}\text { Paracellular } \\
(\% / \mathrm{h})\end{array}$}} & \multirow{2}{*}{\multicolumn{2}{|c|}{$\begin{array}{c}\text { TEER } \\
\left(\Omega \cdot \mathrm{cm}^{2}\right)\end{array}$}} \\
\hline & & \multicolumn{2}{|c|}{$\begin{array}{l}\text { nmol/well per } \\
\text { min }\end{array}$} & \multicolumn{2}{|c|}{$\% / h$} & & & & & & \\
\hline & & Mean & SE & Mean & SE & Mean & SE & Mean & SE & Mean & SE \\
\hline Control & 16 & $0.42^{a}$ & 0.03 & $1.94^{\mathrm{a}}$ & $0 \cdot 10$ & $0.37^{\mathrm{a}}$ & 0.02 & $0.23^{a}$ & 0.02 & $748^{a}$ & 22 \\
\hline $1 \mathrm{nM}-1,25(\mathrm{OH})_{2} \mathrm{D}_{3}$ & 17 & $0.50^{\mathrm{b}}$ & 0.02 & $2 \cdot 26^{\mathrm{b}}$ & 0.06 & $0.45^{\mathrm{b}}$ & 0.02 & $0.19^{a}$ & 0.01 & $710^{a}$ & 24 \\
\hline $10 \mathrm{~nm}-17 \beta$-Oestradiol & 18 & $0.39^{\mathrm{ac}}$ & 0.02 & $1.77^{\mathrm{ac}}$ & $0 \cdot 10$ & $0.34^{\mathrm{ac}}$ & 0.02 & $0.23^{a}$ & 0.02 & $747^{a}$ & 21 \\
\hline $50 \mu \mathrm{M}$-Genistein & 9 & $0.34^{\mathrm{c}}$ & 0.02 & $1 \cdot 60^{\mathrm{C}}$ & 0.09 & $0.30^{c}$ & 0.02 & $0.22^{a}$ & 0.01 & $727^{\mathrm{a}}$ & 33 \\
\hline $50 \mu \mathrm{M}$-Daidzein & 9 & $0.35^{\mathrm{c}}$ & 0.02 & $1.66^{c}$ & 0.07 & $0.30^{C}$ & 0.02 & $0.20^{a}$ & 0.02 & $755^{\mathrm{a}}$ & 29 \\
\hline $\begin{array}{l}\text { Statistical significance of effect } \\
\text { (one-way ANOVA): } P\end{array}$ & & 0.0 & & $\leq 0$ & & $\leq 0$ & & & & 0.6 & \\
\hline
\end{tabular}

TEER, transepithelial electrical resistance (after $24 \mathrm{~h}$ exposure to the different treatments).

${ }_{a, b, c}$ Mean values within a column with unlike superscript letters were significantly different (ANOVA followed by least significant difference test, $P<0.05$ ).

${ }^{*}$ For details of procedures, see p. 756.

†Treatments were given for $24 \mathrm{~h}$ before measurement of calcium transport.

$\ddagger$ Transcellular transport is total calcium transport corrected for paracellular (fluorescein) transport (for details, see p. 756).

which FBS and Phenol Red had been withdrawn for $72 \mathrm{~h}$ (i.e. low-oestrogen conditions) previous to their exposure to $10 \mathrm{nM}-17 \beta$-oestradiol or $50 \mu \mathrm{M}$-genistein or -daidzein for $24 \mathrm{~h}$ (Table 3). Similarly, $50 \mu \mathrm{M}$-genistein or -daidzein had no effect on TEER in these monolayers. Treatment of the Caco- 2 monolayers with $1 \mathrm{nM}-1,25(\mathrm{OH})_{2} \mathrm{D}_{3}$ for $24 \mathrm{~h}$, after the period of low-oestrogen exposure, significantly $(P<0.05)$ increased total transepithelial and transcellular $\mathrm{Ca}$ transport, whereas TEER and paracellular $\mathrm{Ca}$ transport were unaffected (Table 3). Mean TEER values (range $1545-1721 \Omega \cdot \mathrm{cm}^{2}$ ) in these Caco-2 cell monolayers were significantly greater than those in monolayers grown in oestrogen-replete media (range $402-748 \Omega \cdot \mathrm{cm}^{2}$ ).

mRNA levels for calbindin $\mathrm{D}_{9 \mathrm{~K}}$ were significantly $(P<0.01)$ increased in Caco-2 cells (grown in media containing FBS and Phenol Red) exposed to $1 \mathrm{nM}-$ $1,25(\mathrm{OH})_{2} \mathrm{D}_{3}$ for $24 \mathrm{~h}$ compared with that in cells exposed to dimethyl sulfoxide (control) (Fig. 4). mRNA levels for calbindin $D_{9 \mathrm{~K}}$ were unaffected in Caco-2 cells (grown in media containing FBS and Phenol Red) which were exposed to $10 \mathrm{nM}-17 \beta$-oestradiol or $50 \mu \mathrm{M}$ genistein or -daidzein for $24 \mathrm{~h}$, relative to control values (Fig. 4).

\section{Discussion}

As expected, in the present study exposing Caco- 2 cell monolayers in culture to $1 \mathrm{nM}-1,25(\mathrm{OH})_{2} \mathrm{D}_{3}$ for $24 \mathrm{~h}$ stimulated total transepithelial $\mathrm{Ca}$ transport. This finding is in agreement with the findings of other studies that have found that physiological concentrations of $1,25(\mathrm{OH})_{2} \mathrm{D}_{3}$ enhanced $\mathrm{Ca}$ transport in Caco-2 cells (Giuliano \& Wood, 1991; Fleet \& Wood, 1994, 1999; Fleet et al. 1996; Chirayath et al. 1998; Shao et al. 2001). In the present study, the enhancement of total transepithelial $\mathrm{Ca}$ transport by $1,25(\mathrm{OH})_{2} \mathrm{D}_{3}$ was accompanied

Table 2. Effect of genistin, diadzin and 1,25-dihydroxycholecalciferol $\left(1,25(\mathrm{OH})_{2} \mathrm{D}_{3}\right)$ on calcium transport in Caco-2 cell monolayers cultured in oestrogen-replete media*

(Mean values with their standard errors)

\begin{tabular}{|c|c|c|c|c|c|c|c|c|c|c|c|}
\hline \multirow[b]{4}{*}{ Treatment† } & \multirow[b]{4}{*}{$n$} & \multicolumn{8}{|c|}{ Calcium transport } & & \\
\hline & & \multicolumn{4}{|c|}{ Total transepithelial } & \multirow{2}{*}{\multicolumn{2}{|c|}{$\begin{array}{c}\text { Transcellular } \\
\text { (nmol/well per } \\
\text { min) } \ddagger\end{array}$}} & \multirow{2}{*}{\multicolumn{2}{|c|}{$\begin{array}{l}\text { Paracellular } \\
(\% / \mathrm{h})\end{array}$}} & \multirow{2}{*}{\multicolumn{2}{|c|}{$\begin{array}{c}\text { TEER } \\
\left(\Omega \cdot \mathrm{cm}^{2}\right)\end{array}$}} \\
\hline & & \multicolumn{2}{|c|}{$\begin{array}{l}\text { nmol/well per } \\
\text { min }\end{array}$} & \multicolumn{2}{|c|}{$\% / h$} & & & & & & \\
\hline & & Mean & SE & Mean & SE & Mean & SE & Mean & SE & Mean & SE \\
\hline Control & 10 & $0.69^{a}$ & 0.02 & $3 \cdot 16^{a}$ & 0.05 & $0.65^{\mathrm{a}}$ & 0.02 & $0 \cdot 23^{a}$ & 0.01 & $409^{a}$ & 10 \\
\hline $1 \mathrm{nM}-1,25(\mathrm{OH})_{2} \mathrm{D}_{3}$ & 11 & $0.78^{b}$ & 0.02 & $3.56^{b}$ & 0.06 & $0.72^{b}$ & 0.02 & $0.28^{a}$ & 0.02 & $415^{a}$ & 10 \\
\hline $50 \mu \mathrm{M}-$ Genistin & 10 & $0.64^{a}$ & 0.02 & $3 \cdot 04^{a}$ & 0.08 & $0.59^{a}$ & 0.02 & $0.27^{a}$ & 0.03 & $411^{a}$ & 11 \\
\hline $50 \mu \mathrm{M}$-Diadzin & 11 & $0 \cdot 65^{a}$ & 0.03 & $3 \cdot 03^{a}$ & 0.07 & $0.60^{a}$ & 0.03 & $0.25^{a}$ & 0.02 & $402^{\mathrm{a}}$ & 7 \\
\hline \multicolumn{2}{|l|}{$\begin{array}{l}\text { Statistical significance of effect } \\
\text { (one-way ANOVA): } P\end{array}$} & \multicolumn{2}{|c|}{0.0007} & \multicolumn{2}{|c|}{$\leq 0.0001$} & \multicolumn{2}{|c|}{0.0009} & \multicolumn{2}{|c|}{0.277} & \multicolumn{2}{|c|}{0.800} \\
\hline
\end{tabular}

TEER, transepithelial electrical resistance (after $24 \mathrm{~h}$ exposure to the different treatments).

${ }^{a, b}$ Mean values within a column with unlike superscript letters were significantly different (ANOVA followed by least significant difference test, $P<0.05$ ).

${ }^{*}$ For details of procedures, see p. 756.

†Treatments were given for $24 \mathrm{~h}$ before measurement of calcium transport.

$\ddagger$ Transcellular transport is total calcium transport corrected for paracellular (fluorescein) transport (for details, see p. 756). 
Table 3. Effect of $17 \beta$-oestradiol, genistein, diadzein and 1,25-dihydroxycholecalciferol $\left(1,25(\mathrm{OH})_{2} \mathrm{D}_{3}\right)$ on calcium transport in Caco-2 cell monolayers cultured in oestrogen-deplete media*

(Mean values with their standard errors)

\begin{tabular}{|c|c|c|c|c|c|c|c|c|c|c|c|}
\hline \multirow[b]{4}{*}{ Treatment† } & \multirow[b]{4}{*}{$n$} & \multicolumn{8}{|c|}{ Calcium transport } & & \\
\hline & & \multicolumn{4}{|c|}{ Total transepithelial } & \multirow{2}{*}{\multicolumn{2}{|c|}{$\begin{array}{l}\text { Transcellular } \\
\text { (nmol/well per } \\
\text { min) } \ddagger\end{array}$}} & \multirow{2}{*}{\multicolumn{2}{|c|}{$\begin{array}{l}\text { Paracellular } \\
(\% / \mathrm{h})\end{array}$}} & \multirow{2}{*}{\multicolumn{2}{|c|}{$\begin{array}{l}\text { TEER } \\
\left(\Omega \cdot \mathrm{cm}^{2}\right)\end{array}$}} \\
\hline & & \multicolumn{2}{|c|}{$\begin{array}{l}\mathrm{nmol} / \text { well per } \\
\min \end{array}$} & \multicolumn{2}{|c|}{$\% / h$} & & & & & & \\
\hline & & Mean & SE & Mean & SE & Mean & SE & Mean & $\mathrm{SE}$ & Mean & $\mathrm{SE}$ \\
\hline Control & 10 & $0.34^{a}$ & 0.05 & $2 \cdot 29^{a}$ & 0.24 & $0.30^{\mathrm{a}}$ & 0.04 & $0.38^{\mathrm{a}}$ & 0.04 & $1721^{a}$ & 47 \\
\hline $1 \mathrm{nM}-1,25(\mathrm{OH})_{2} \mathrm{D}_{3}$ & 8 & $0.59^{b}$ & 0.06 & $3.45^{\mathrm{b}}$ & 0.45 & $0.51^{\mathrm{b}}$ & 0.07 & $0.40^{\mathrm{a}}$ & 0.07 & $1664^{a}$ & 99 \\
\hline $10 \mathrm{~nm}-17 \beta$-Oestradiol & 8 & $0.32^{\mathrm{a}}$ & 0.03 & $2 \cdot 43^{\mathrm{a}}$ & 0.20 & $0.27^{\mathrm{a}}$ & 0.02 & $0.39^{\mathrm{a}}$ & 0.02 & $1545^{\mathrm{a}}$ & 31 \\
\hline $50 \mu \mathrm{M}-$ Genistein & 10 & $0.41^{a}$ & 0.07 & $2 \cdot 08^{\mathrm{a}}$ & 0.35 & $0.30^{\mathrm{a}}$ & 0.04 & $0.42^{\mathrm{a}}$ & 0.03 & $1560^{\mathrm{a}}$ & 26 \\
\hline $50 \mu \mathrm{M}$-Diadzein & 10 & $0.36^{a}$ & 0.05 & $2 \cdot 32^{\mathrm{a}}$ & 0.29 & $0.31^{a}$ & 0.04 & $0.36^{\mathrm{a}}$ & 0.05 & $1656^{\mathrm{a}}$ & 63 \\
\hline $\begin{array}{l}\text { Statistical significance } \\
\text { of effect (one-way ANOVA): } P\end{array}$ & & & & & & & & & & 0.2 & \\
\hline
\end{tabular}

TEER, transepithelial electrical resistance (after $24 \mathrm{~h}$ exposure to the different treatments).

a,b Mean values within a column with unlike superscript letters were significantly different (ANOVA followed by least significant difference test, $P<0 \cdot 05$ ).

* For details of procedures, see p. 756.

†Treatments were given for $24 \mathrm{~h}$ before measurement of calcium transport.

‡Transcellular transport is total calcium transport corrected for paracellular (fluorescein) transport (for details, see p. 760).

by an increased transcellular Ca transport, whereas paracellular $\mathrm{Ca}$ transport was unaffected. This finding is in agreement with the findings of several other studies (Giuliano \& Wood, 1991; Fleet \& Wood, 1994, 1999; Fleet et al. 1996). The significant enhancement of total transepithelial $\mathrm{Ca}$ transport by $1,25(\mathrm{OH})_{2} \mathrm{D}_{3}$ in the present study acted as a positive control for our present experiments to investigate the influence of $17 \beta$-oestradiol and dietary PO on Ca transport in the Caco- 2 model.

In the present study, treatment with $10 \mathrm{nM}-17 \beta$-oestradiol for $24 \mathrm{~h}$ had no effect on total transepithelial Ca transport in differentiated Caco-2 cells (grown in FBS-Phenol Red-containing media). The concentration of $17 \beta$-oestradiol $(10 \mathrm{~nm})$ used in the present study, while high in terms of physiological circulating concentrations (typically about 325 and $75 \mathrm{pm}$ in hormone replacement therapy-treated and non-treated postmenopausal women, respectively; Morabito et al. 2002), was chosen as it has been shown to significantly $(P<0.05)$ increase $\mathrm{Ca}$ uptake in rat duodenal cells in vitro (Arjmandi et al. 1993). These findings agree with preliminary findings that suggest that $100 \mathrm{nM}-$ $17 \beta$-oestradiol does not influence $\mathrm{Ca}$ transport in Caco-2 cells grown in oestrogen-replete media ( $\mathrm{S}$ Taparia and $\mathrm{RJ}$ Wood, personal communication). To test whether $17 \beta$-oestradiol might stimulate $\mathrm{Ca}$ transport in $\mathrm{Caco}-2$ cells maintained in an oestrogen-depleted environment, the experiments were repeated in Caco- 2 cell monolayers that were grown in media devoid of FBS and Phenol Red (which may have some oestrogenic activity; Welshons et al. (1988)) for $72 \mathrm{~h}$ before their exposure to $17 \beta$-oestradiol for a subsequent $24 \mathrm{~h}$. However, under these conditions of low oestrogen status, 17 $\beta$-oestradiol (10 nM) had no effect on $\mathrm{Ca}$ transport in Caco- 2 cells. These in vitro findings, however, appear to be in contrast to the findings in oestrogen-depleted ovariectomized rats (O’Loughlin \& Morris, 1998; Colin et al. 1999; Ten Bolscher et al. 1999; Arjmandi et al. 2000) and postmenopausal women (Heaney et al. 1978; Gallagher et al. 1980; for review, see Gallagher, 1990), which suggest that oestrogen stimulates $\mathrm{Ca}$ absorption in vivo.

Ten Bolscher et al. (1999) suggest that oestrogen stimulates intestinal $\mathrm{Ca}$ absorption in vivo via an OR-mediated effect. The Caco- 2 cells used in the present study expressed mRNA for OR $\beta$ but not $-\alpha$. These findings are in agreement with the recent findings of Campbell-Thompson et al. (2001) which show that OR $\beta$ message and protein were expressed in Caco- 2 cells, but that $\mathrm{OR} \alpha \mathrm{mRNA}$ were undetectable. Campbell-Thompson et al. (2001), on the other hand, showed that normal human colonic mucosa as well as colon tumour samples expressed mRNA for OR $\alpha$ and $-\beta$, with mRNA for OR $\alpha$ being much lower than for OR $\beta$. The lack of mRNA for OR $\alpha$, and presumably of the $\mathrm{OR} \alpha$ protein in the Caco- 2 cells in the present study, although this was not determined, might, partly explain the lack of stimulatory effect of $17 \beta$-oestradiol on Ca transport. In the present study, addition of $10 \mathrm{nM}-17 \beta$-oestradiol to a Phenol Red-free medium containing a charcoalstripped, heat-inactivated FBS induced a proliferative effect in subconfluent, undifferentiated Caco-2 cells. Furthermore, hydroxytamoxifen, a partial oestrogen agonist, inhibited this proliferative effect. These findings, collectively, would suggest that the Caco- 2 cells used in the present study were capable of a functional response to $17 \beta$-oestradiol. These findings are in agreement with those of Di Domenico et al. (1996), who investigated the functionality of the OR in Caco- 2 cells.

The findings of the present study in the Caco- 2 cell model suggest that genistein and daidzein, two commonly consumed soyabean-based PO, at relatively high concentrations reduced intestinal absorption of $\mathrm{Ca}$. The concentration of isoflavones used in the present study (i.e. $50 \mu \mathrm{M})$ was chosen to reflect luminal (small intestine) concentrations in subjects participating in the various dietary intervention trials which have investigated the effect of PO on bone (Dalais et al. 1998; Potter et al. 1998; Alekel et al. 2000; Hsu et al. 2001; Morabito et al. 2002). This is 
(A)

\begin{tabular}{l|l|l|l|l|l|l|}
\hline Treatment... & Marker & DMSO & $1,25 \mathrm{D}$ & Oestrogen & G & D \\
\hline
\end{tabular}
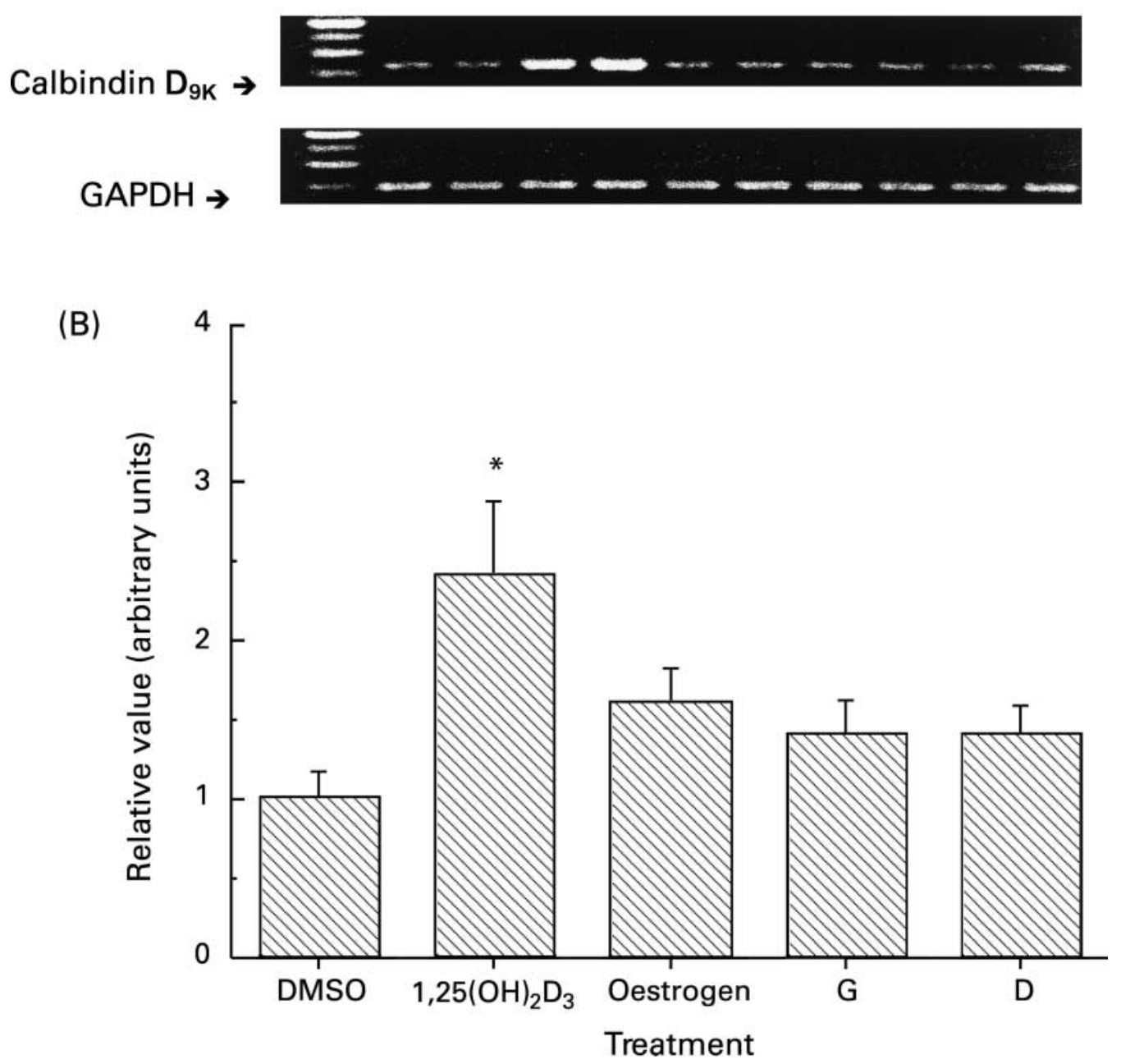

Fig. 4. Effect of treatment for $24 \mathrm{~h}$ on calbindin $\mathrm{D}_{9 \mathrm{~K}}$ accumulation in Caco-2 cells. Treatments were: dimethyl sulfoxide (DMSO, control); $1 \mathrm{nM}-$ 1,25-dihydroxycholecalciferol $\left(1,25\left(\mathrm{OH}_{2}\right) \mathrm{D}_{3}\right) ; 10 \mathrm{nM}$-17ß-oestradiol (oestrogen); $50 \mu \mathrm{M}$-genistein (G); $50 \mu \mathrm{M}$-daidzein (D). Marker, 500 (double band), 400, 300 and $200 \mathrm{bp}$. Calbindin $\mathrm{D}_{9 \mathrm{~K}}$ mRNA levels were assessed by reverse transcriptase-polymerase chain reaction and normalized to glyceraldehyde-3-phosphate dehydrogenase (GAPDH) expression. For details of procedures, see p. 756. (A), a representative gel from one experiment $(n 2)$; (B), relative expression of calbindin $D_{9 k}$ mRNA levels. Values are means with their standard errors shown by vertical bars for at least six wells per treatment. The effect of treatment was analysed by one-way ANOVA followed by least significant difference test. Mean value was significantly different from that of the control: ${ }^{*} P<0.05$.

the first study, to our knowledge, to investigate the effect of $\mathrm{PO}$ on $\mathrm{Ca}$ absorption in a human intestinal cell line. These in vitro findings were unexpected because soyabean milks (rich sources of genistein and daidzein) have been shown to enhance $\mathrm{Ca}$ balance in experimental animals (Omi et al. 1992, 1994). For example, Omi et al. (1994) reported that intestinal $\mathrm{Ca}$ absorption, determined using the metabolic balance approach on three separate occasions throughout a $28 \mathrm{~d}$ feeding period, was significantly $(P<0.05)$ greater in ovariectomized rats given a soyabean milk-containing diet than in rats given a control diet (containing no soyabean milk). Moreover, Arjmandi et al. (2002) recently reported that the rates of in vitro Ca transport by duodenal, ileal, and colonic cells of ovariectomized rats fed soyabean protein with normal isoflavone content were significantly $(P<0 \cdot 05)$ greater than those from ovarectomized control animals. Interestingly, in that study an isoflavone-deplete soyabean protein also significantly $(P<0 \cdot 05)$ increased Ca transport by ileal cells, but not duodenal or colonic cells (Arjmandi et al. 2002), suggesting that perhaps the soyabean protein itself enhances the $\mathrm{Ca}$ transport even in the absence of isoflavones. The effect of isolated $\mathrm{PO}$ compounds on $\mathrm{Ca}$ absorption in rats has not been reported. However, Arjmandi et al. (2000) reported that ipriflavone, a synthetic PO, enhanced in vitro intestinal $\mathrm{Ca}$ transport in an ovariectomized rat model. In their model system, consumption of ipriflavone approximately doubled $(P<0.05)$ the in vitro $\mathrm{Ca}$ uptake by intestinal cells from ovariectomized rats compared with that in cells from animals fed the control diet. 
It should be noted that these studies were carried out in ovariectomized animals that would be expected to have a low endogenous oestrogen status. Therefore, to test whether the genistein and daidzein might stimulate $\mathrm{Ca}$ transport in Caco-2 cell monolayers in conditions of reduced oestrogen status, the $\mathrm{Ca}$ transport experiments in the present study were repeated in Caco- 2 cell monolayers that were grown in media devoid of FBS and Phenol Red for $72 \mathrm{~h}$ before their exposure to the PO compounds for a subsequent $24 \mathrm{~h}$. Under these conditions of low oestrogen status, the inhibitory effect of the two PO on Ca transport disappeared, but also of note, there was no evidence of a stimulatory effect on $\mathrm{Ca}$ transport.

It is possible that the inhibitory effect of the two PO, at high luminal concentrations, on $\mathrm{Ca}$ transport in $\mathrm{Caco}-2$ cells grown in oestrogen-replete conditions in the present study was due to their binding to the OR $\beta$ in the intestinal cells and hence competitively inhibiting oestrogen uptake. This mechanism is believed to underpin the inhibitory effect of isoflavones on breast and colon tumour growth (Messina et al. 1994; Zava \& Duwe, 1997). Anderson et al. (1998) reported biphasic effects of genistein on rat bone tissue, whereby at low doses, genistein appears to be an agonist at the OR locus, whereas at higher doses, it is less effective and may even have adverse effects on bone cells. In light of this biphasic activity, the effect of lower concentrations of these isoflavones on $\mathrm{Ca}$ transport in Caco- 2 cells warrants investigation.

Genistein and other isoflavones bind only weakly with the OR $\alpha$ but complex with OR $\beta$ almost as well as oestrogens (Kuiper et al. 1997). As already mentioned earlier, the Caco- 2 cells in the present study expressed mRNA for the OR $\beta$ and, presumably expressed the OR $\beta$ protein, although this was not determined. Interestingly, in the present study, genistin and daidzin, which do not have oestrogenic activity (Miksicek, 1995), did not influence transepithelial $\mathrm{Ca}$ transport, suggesting that the inhibition of $\mathrm{Ca}$ transport was only associated with the aglycoside form of these isoflavones (i.e. genistein and daidzein) and not their respective glycoside. The reduction in total transepithelial $\mathrm{Ca}$ transport in Caco-2 cells treated with genistein and daidzein in the present study occurred by a down-regulation of the transcellular $\mathrm{Ca}$ transport process. The mechanism for this down-regulation is unclear. There is some evidence of a regulatory effect of dietary PO on Ca-binding proteins. For example, Taylor et al. (1999) reported that calbindin $\mathrm{D}_{28 \mathrm{~K}}$ protein levels in the brain of female fetuses from pregnant rats fed a $\mathrm{PO}$-free diet were significantly $(P<0.05)$ greater than those in the brains of fetuses from pregnant rats fed a PO-containing diet. Similarly, Lephart et al. (2000) showed that consumption of PO, in the form of soyabean-based diets, for 5 weeks lead to a significant $(P<0.05)$ decrease in calbindin levels in the brain of male rats relative to that in control animals fed a PO-free diet. In the present study, mRNA levels for the intestinal Ca-binding protein (calbindin $\mathrm{D}_{9 \mathrm{~K}}$ ), which is proposed to function as either an intracellular $\mathrm{Ca}$ buffer or an intracellular ferry protein that facilitates diffusion of $\mathrm{Ca}$ across the enterocyte (Bronner et al. 1986), were unaffected by either genistein or daidzein treatment. As expected, $1,25(\mathrm{OH})_{2} \mathrm{D}_{3}$ treatment significantly $(P<0.01)$ increased the levels of mRNA for calbindin $D_{9 \mathrm{~K}}$ in the Caco-2 cells used in the present study. This finding is in agreement with similar findings of several other studies (Fleet \& Wood, 1994, 1999; Fleet et al. 1996; Wood et al. 2001). Transcription of calbindin $\mathrm{D}_{9 \mathrm{~K}}$ gene in Caco- 2 cells was also unaffected by $17 \beta$-oestradiol, even though this gene has an oestrogen response element (Klinge, 2001).

The down-regulation of transcellular $\mathrm{Ca}$ transport by $\mathrm{PO}$ may arise by a non-genomic effect. For example, genistein has been reported to directly inhibit the activity of certain cellular regulatory proteins, including tyrosine kinases and topoisomerases (Akiyama et al. 1987; Markovits et al. 1989). Inhibition of tyrosine kinases may adversely effect $\mathrm{Ca}$ transport since they are involved in $1,25(\mathrm{OH})_{2} \mathrm{D}_{3}$ induced translocation of the vitamin $\mathrm{D}$ receptor from nucleus to the plasma membrane (Capiati et al. 2002). At the plasma membrane, the vitamin $\mathrm{D}$ receptor may mediate rapid, non-genomic responses, such as transcaltachia (the rapid hormonal stimulation of intestinal $\mathrm{Ca}$ transport) (Norman et al. 2002).

In conclusion, the findings of the present study would suggest that the beneficial effects of supplemental levels of PO compounds, such as genistein and daidzein, on bone mass in postmenopausal women (Dalais et al. 1998; Potter et al. 1998; Morabito et al. 2002) are more likely to arise from direct effects on bone cells, and not by an indirect effect of these compounds on $\mathrm{Ca}$ absorption. However, as these compounds exhibit biphasic effects in some tissues, the effect of lower concentrations of genistein and daidzein on intestinal $\mathrm{Ca}$ absorption requires further investigation.

\section{Acknowledgement}

This work was supported by funding made available under the National Development Plan 2000-2006 with assistance from the European Regional Development Fund.

\section{References}

Agnusdei D, Crepaldi G, Isaia G, Mazzuoli G, Ortolani S, Passeri M, Bufalino L \& Gennari C (1997) A double blind, placebo-controlled trial of ipriflavone for prevention of postmenopausal spinal bone loss. Calcified Tissue International 61, 142-147.

Akiyama T, Ishida J \& Nakagawa S (1987) Genistein: a specific inhibitor of tyrosine-specific protein kinase. Journal of Biological Chemistry 262, 5592-5595.

Alekel DL, Germain AS, Peterson CT, Hanson KB, Stewart JW \& Toda T (2000) Isoflavone-rich soy protein isolate attenuates bone loss in the lumbar spine of perimenopausal women. American Journal of Clinical Nutrition 72, 844-852.

Anderson JJ, Ambrose WW \& Garner SC (1998) Biphasic effects of genistein on bone tissue in the ovariectomised, lactating rat model. Proceedings of the Society for Experimental Biology and Medicine 217, 345-350.

Anderson JJB, Anthony M, Messina M \& Garner SC (1999) Effects of phytoestrogens in tissues. Nutrition Research Reviews 12, 75-116.

Arai N, Strom A, Rafter JJ \& Gustafsson JA (2000) Estrogen receptor beta mRNA in colon cancer cells: growth effects of 
estrogen and genistein. Biochemical and Biophysical Research Communications 13, 425-431.

Arjmandi BH \& Smith BJ (2002) Soy isoflavones' osteoprotective role in postmenopausal women: mechanism of action. Journal of Nutritional Biochemistry 13, 130-137.

Arjmandi BH (2001) The role of phytoestrogens in the prevention and treatment of osteoporosis in ovarian hormone deficiency. Journal of American College Nutrition 20, 398S-402S.

Arjmandi BH, Alekel L, Hollis BW, Amin D, StacewiczSapuntzakis M, Guo P \& Kukreja SC (1996) Dietary soybean protein prevents bone loss in an ovariectomized rat model of osteoporosis. Journal of Nutrition 126, 161-167.

Arjmandi BH, Birnbaum R, Goyal NV, Getlinger MJ, Juma S, Alekel L, Hasler CM, Drum ML, Hollis BW \& Kukreja SC (1998a) Bone-sparing effect of soy protein in ovarian hormone-deficient rats is related to its isoflavone content. American Journal of Clinical Nutrition 68, 1346S-1368S.

Arjmandi BH, Getlinger MJ, Goyal NV, Alekel L, Hasler CM, Juma S, Drum ML, Hollis BW \& Kukreja SC (1998b) Role of soy protein with normal or reduced isoflavone content in reversing bone loss induced ovarian hormone deficiency in rats. American Journal of Clinical Nutrition 68, 1358S-1363S.

Arjmandi BH, Khalil DA \& Hollis BW (2000) Ipriflavone, a synthetic phytoestrogen, enhances intestinal calcium transport in vitro. Calcified Tissue International 67, 225-229.

Arjmandi BH, Khalil DA \& Hollis BW (2002) Soy protein: its effect on intestinal calcium transport, serum vitamin $\mathrm{D}$, and insulin-like growth factor-1 in various ovariectomized rats. Calcified Tissue International 70, 483-487.

Arjmandi BH, Salih MA, Herbert DC, Sims SH \& Kalu DN (1993) Evidence for estrogen receptor-linked calcium transport in the intestine. Bone and Mineral 21, 63-74.

Blair HC, Jordan SE, Peterson TG \& Barnes S (1996) Variable effects of tyrosine kinase inhibitors on avian osteoclastic activity and reduction of bone loss in ovariectomised rats. Journal of Cell Biochemistry 61, 629-637.

Bronner F, Pansu D \& Stein WD (1986) An analysis of intestinal calcium transport across the rat intestine. American Journal of Physiology 250, G561-G569.

Campbell-Thompson M, Lynch IJ \& Bhardwaj B (2001) Expression of estrogen receptor (ER) subtypes and ERbeta isoforms in colon cancer. Cancer Research 61, 632-640.

Capiati D, Benassati S \& Boland RL (2002) 1,25(OH) 2 -vitamin $\mathrm{D}_{3}$ induces translocation of the vitamin $\mathrm{D}$ receptor (VDR) to the plasma membrane in skeletal muscle cells. Journal of Cell Biochemistry 86, 128-135.

Cassidy A (1996) Physiological effects of phyto-oestrogens in relation to cancer and other human health risks. Proceedings of the Nutrition Society 55, 399-417.

Chirayath MV, Gajdzik L, Hulla W, Graf J, Cross HS \& Peterlik M (1998) Vitamin D increases tight-junction conductance and paracellular $\mathrm{Ca}^{2+}$ transport in Caco-2 cell cultures. American Journal of Physiology 274, G389-G396.

Colin EM, Van Den Bemd GJ, Van Aken M, Christakos S, De Jonge HR, Deluca HF, Prahl JM, Birkenhager JC, Buurman CJ, Pols HA \& Van Leeuwen JP (1999) Evidence for involvement of 17 beta-estradiol in intestinal calcium absorption independent of 1,25-dihydroxyvitamin D3 level in the rat. Journal of Bone and Mineral Research 14, 57-64.

Dalais FS, Rice GE, Wahlquist ML, Grehan M, Murkies AL, Medley G, Ayton R \& Strauss BJG (1998) Effects of dietary phytoestrogens in postmenopausal women. Climacteric $\mathbf{1}$, $124-129$.

Di Domenico M, Castoria G, Bilancio A, Migliaccio A \& Auricchio F (1996) Estradiol activation of human colon carcinoma-derived Caco-2 cell growth. Cancer Research 56, 4516-4521.
Edmonson JM, Armstrong LS \& Martinez AO (1988) A rapid and simple MTT-based assay for determining drug sensitivity in monolayer cultures. Journal of Tissue Culture Methods 11, $15-17$.

Fleet JC \& Wood RJ (1994) Identification of calbindin D-9k mRNA and its regulation by 1,25-dihydroxyvitamin $D_{3}$ in Caco-2 cells. Archives of Biochemistry and Biophysics 308, $171-174$

Fleet JC \& Wood RJ (1999) Specific 1,25(OH) $)_{2} \mathrm{D}_{3}$-mediated regulation of transcellular calcium transport in Caco-2 cells. American Journal of Physiology 276, G958-G964.

Fleet JC, Bradley J, Reddy GS, Ray R \& Wood RJ (1996) 1 alpha, 25- $(\mathrm{OH})_{2}$-vitamin $\mathrm{D}_{3}$ analogs with minimal in vivo calcemic activity can stimulate significant transepithelial calcium transport and mRNA expression in vitro. Archives of Biochemistry and Biophysics 15, 228-234.

Gallagher JC (1990) The pathogenesis of osteoporosis. Bone Mineral 9, 215-227.

Gallagher JC (2001) Role of estrogens in the management of postmenopausal bone loss. Rheumatic Diseases Clinics of North America 27, 143-162.

Gallagher JC, Riggs BL \& DeLuca HF (1980) Effect of estrogen on calcium absorption and serum vitamin D metabolites in postmenopausal osteoporosis. Journal of Clinical Endocrinology and Metabolism 51, 1359-1364.

Gao YH \& Yamaguchi M (2000) Suppressive effect of genistein on rat bone osteoclasts: Involvement of protein kinase inhibition and protein tyrosine phosphatase activation. International Journal of Molecular Medicine 5, 261-267.

Gennari C, Agnusdei D, Crepaldi G, Isaia G, Mazzuoli G, Ortolani S, Bufalino L \& Passeri M (1998) Effect of ipriflavone - a synthetic derivative of natural isoflavones - on bone mass loss in the early years after menopause. Menopause 5, 9-15.

Giuliano AR, Franceschi RT \& Wood RJ (1991) Characterization of the vitamin D receptor from the Caco-2 human colon carcinoma cell line: effect of cellular differentiation. Archives of Biochemistry and Biophysics 285, 261-269.

Giuliano AR \& Wood RJ (1991) Vitamin D-regulated calcium transport in Caco-2 cells: unique in vitro model. American Journal of Physiology 260, G207-G212.

Heaney RP, Recker RR \& Saville PD (1978) Menopausal changes in calcium balance performance. Journal of Laboratory and Clinical Medicine 92, 953-963.

Hsu CS, Shen WW, Hsueh YM \& Yeh SL (2001) Soy isoflavone supplementation in postmenopausal women. Effects on plasma lipids, antioxidant enzyme activities and bone density. Journal of Reproductive Medicine 46, 221-226.

Hunt SM, Chrzanowski C, Barnett CR, Brand HN \& Fawell JK (1987) A comparison of in vitro cytotoxicity assays and their application to water samples. Alternatives to Laboratory Animals 15, 20-29.

Klinge CM (2001) Estrogen receptor interaction with estrogen response elements. Nucleic Acids Research 29, 2905-2919.

Kuiper GG, Carlsson B, Grandien K, Enmark E, Haggblad J, Nilsson S \& Gustafsson JA (1997) Comparison of the ligand binding specificity and transcript tissue distribution of estrogen receptors alpha and beta. Endocrinology 138, $863-870$.

Lephart ED, Thompson JM, Setchell KD, Adlercreutz H \& Weber KS (2000) Phytoestrogens decrease brain calciumbinding proteins but do not alter hypothalmic androgen metabolizing enzymes in adult male rat. Brain Research 859, $123-131$

Lindmark T, Kimura Y \& Artursson P (1998) Absorption enhancement through intracellular regulation of tight junction permeability by medium chain fatty acids in Caco- 2 cells. 
Journal of Pharmacology and Experimental Therapeutics 284, 362-369.

Markovits J, Linassier C, Fosse P, Couprie J, Pierre J, JacqueminSablon A, Saucier JM, Le Pecq JB \& Larsen AK (1989) Inhibitory effects of the tyrosine kinase inhibitor genistein on mammalian DNA topoisomerase II. Cancer Research 49, 5111-5117.

Messina MJ, Persky V, Setchell KD \& Barnes S (1994) Soy intake and cancer risk: a review of the in vitro and in vivo data. Nutrition and Cancer 21, 113-131.

Miksicek RJ (1995) Estrogenic flavonoids: structural requirements for biological activity. Proceedings of the Society for Experimental Biology and Medicine 208, 44-50.

Morabito N, Crisafulli A, Vergara C, Gaudio A, Lasco A, Frisina N, D’Anna R, Corrado F, Pizzoleo MA, Cincotta M, Altavilla D, Ientile R \& Squadrito F (2002) Effects of genistein and hormone-replacement therapy on bone loss in early postmenopausal women: a randomized double-blind placebo-controlled study. Journal of Bone and Mineral Research 17, 1904-1912.

Mossman T (1983) Rapid colorimetric assay for cellular growth and survival: application to proliferation and cytotoxicity assays. Journal of Immunological Methods 65, 55-63.

Nguyen TV, Jones G, Sambrook PN, White CP, Kelly PJ \& Eisman JA (1995) Effects of estrogen exposure and reproductive factors on bone mineral density and osteoporotic fractures. Journal of Clinical Endocrinology and Metabolism 80, 2709-2714.

Norman AW, Okamura WH, Bishop JE \& Henry HL (2002) Update on biological actions of $1 \alpha, 25(\mathrm{OH})_{2}$-vitamin $\mathrm{D}_{3}$ (rapid effects) and $24 R, 25(\mathrm{OH})_{2}$-vitamin $\mathrm{D}_{3}$. Molecular and Cellular Endocrinology 197, 1-13.

Ohta H, Komukai S, Makita K, Masuzawa T \& Nozawa S (1999) Effects of 1-year ipriflavone treatment on lumbar bone mineral density and bone metabolic markers in postmenopausal women with low bone mass. Hormone Research 51, $178-183$.

O'Loughlin PD \& Morris HA (1998) Oestrogen deficiency impairs intestinal calcium absorption in the rat. Journal of Physiology 15, 313-322.

Omi N, Aoi S, Murata K \& Ezawa I (1992) The effect of soybean milk on bone mineral density and bone strength in ovariectomized osteoporotic rats. Journal of Home Economics in Japan 44, 549-554.

Omi N, Aoi S, Murata K \& Ezawa I (1994) Evaluation of the effect of soybean milk and soybean milk peptide on bone metabolism in the rat model with ovariectomised osteoporosis. Journal of Nutritional Science and Vitaminology 40, 201-211.

Picherit C, Chanteranne B, Bennetau-Pelissero C, Davicco M-J, Lebecque P, Bartlett J-P \& Coxam V (2001) Dose-dependent bone-sparing effects on dietary isoflavones in the ovariectomised rat. British Journal of Nutrition 85, 307-316.
Picherit C, Coxam V, Bennetau-Pelissero C, Kati-Coulibaly S, Davicco MJ, Lebecque P \& Bartlett JP (2000) Daidzein is more efficient than genistein in preventing ovariectomy-induced bone loss in rats. Journal of Nutrition 130, 1675-1681.

Pinto M, Robine-Leon S, Appay MD, Kedinger M, Triadow N, Dussaulx E, Lacroix B, Simon-Assmann P, Haffer K, Fogh J \& Zweibaum A (1983) Enterocyte-like differentiation and polarization of the human colon carcinoma cell line Caco-2 in culture. Biology of the Cell 47, 323-330.

Potter SM, Baum JA, Teng H, Stillman RJ, Shay NF \& Erdman JW Jr (1998) Soy protein and isoflavones: their effects on blood lipids and bone density in postmenopausal women. American Journal of Clinical Nutrition $\mathbf{6 8}$, 1375S-1379S.

Riggs BL \& Melton LJ 3rd (1986) Involutional osteoporosis. New England Journal of Medicine 26, 1676-1686.

Shao A, Wood RJ \& Fleet JC (2001) Increased vitamin D receptor level enhances 1,25-dihydroxyvitamin $\mathrm{D}_{3}$-mediated gene expression and calcium transport in Caco- 2 cells. Journal of Bone and Mineral Research 16, 615-624.

Snedecor GW \& Cochran WG (1967) Statistical Methods. Ames, IA: Iowa State University Press.

Taylor H, Quintero EM, Iacopino AM \& Lephart ED (1999) Phytoestrogens alter hypothalamic calbindin-D28k levels during prenatal development. Brain Research and Developmental Brain Research 14, 277-281.

Taylor M (1997) Alternatives to conventional hormone replacement therapy. Comprehensive Therapy 23, 514-532.

Ten Bolscher M, Netelenbos JC, Barto R, Van Buuren LM \& Van der vijgh WJ (1999) Estrogen regulation of intestinal calcium absorption in the intact and ovariectomized adult rat. Journal of Bone and Mineral Research 14, 1197-1202.

Vassault A (1983) In Methods of Enzymatic Analysis, 3rd ed., vol. 3, pp. 118-126 [HV Bergmeyer, editor]. Deerfield Beach, FL: VCH Weinheim, West Germany.

Welshons WV, Wolf MF, Murphy CS \& Jordan VC (1988) Estrogenic activity of Phenol Red. Molecular and Cellular Endocrinology 57, 169-178.

Wood RJ, Tchack L \& Taparia S (2001) 1,25-Dihydroxyvitamin D3 increases the expression of the CaT1 epithelial calcium channel in the Caco-2 human intestinal cell line. $B M C$ Physiology 1, 11.

Yamaguchi M \& Sugimoto E (2000) Stimulatory effect of genistein and diadzein on protein synthesis in osteoblastic MC3T3-E1 cells: Activation of aminoacyl-tRNA synthetase. Molecular and Cellular Biochemistry 214, 97-102.

Yee S (1997) In vitro permeability across Caco-2 cells (colonic) can predict in vivo (small intestinal) absorption in man fact or myth. Pharmacological Research 14, 763-766.

Zava DT \& Duwe G (1997) Estrogenic and antiproliferative properties of genistein and other flavonoids in human breast cancer cells in vitro. Nutrition and Cancer 27, 31-40. 